\title{
Learning Through Music Using Quranic Verses In English
}

\author{
Dr Lubna Almenoar
}

\section{Introduction}

Researchers have made conclusive findings on the benefits of using music in the language learning classroom. Merged with the right pedagogical approaches, music can be a contributive factor to the learning of new vocabulary, certain word and phrases enable teachers to elicit interpretive meaning from students, experiential learning can also be sparked up where students can use their own experiences to explain the main message of the lyrics of the whole song. Teachers can also use music to supplement the reading material studies prior to listening to the song. The reading material must have ties with the music chosen. Through good planning, and strategies which enhance the four language skills, music and its lyrics and the literary text, can indeed create a very enjoyable classroom atmosphere. This, in itself would optimize learning.

It is such that the information in the 21 st century reaches us through technological and visual screen forms much more so than the form of the written texts on paper. Media literacy includes the use of media or new technology in an active and critical process of learning and teaching. This study introduces and guides teachers to the media sources or websites to downloadable extracts of the literary texts which are Quranic Verses in English by a variety of translators. Teachers can actually look through and choose the suitable work of a particular translator for classroom use.

This study has incorporated music into the teaching session. Not any kind of music, however, but only music with direct ties in content to the literary text. Thus, for the purpose of this study, the writer has been made aware of a valuable media source of "special songs" which are in direct ties to the content discussed in the Quranic Verses in English chosen for classroom use by this writer. These songs are available online and the title of each of these "special songs" is actually each of the important topics discussed in the Quran. For this study, the direct link to the relevant song to the literary text in content will be given. Teachers can thus download the song on a CD for classroom use.

The full name of the technique, Learning Through Music Using Quranic Verses in English, is an explicit statement informing the literary text chosen for the Critical Reading Classroom. Music is also infused into the teaching session. Music, as an "international language of unity" which people of all cultures enjoy, is used. Additionally, a further attempt is made to locate and use songs with lyrics containing the target vocabulary words or messages as the reading or literary text. Experiential learning is also tied into the session for deeper understanding. While students are listening to the music and singing the song, students are engaged in a pleasurable experience. Students are more relaxed, more attentive and receptive to learning the target vocabulary words which will be modeled in context through the authentic literary text.

In an attempt to integrate, incorporate and promote multicultural practices in the language learning classroom, this writer makes a rigorous effort in selecting classroom materials or literary texts depicting a diversified socio-cultural variety to expose her students to different global human societies. For example, this writer has used Japanese short stories, Chinese poems, lyrics of Spanish songs, all of which were translated into the English language. The text chosen for this technique was selected Quranic verses in English.

In this paper, this writer will:

1. Show how using information technology can assist teachers in the quest of using Quranic verses in English as literary texts or reading material. Some useful websites are in APPENDIX 2.

2. Demonstrate how to use Quranic verses in English. More is done in APPENDIX 3.

3. Show selected verses (APPENDIX 1) and lyrics of Islamic song (APPENDIX 4)

4. Merge selected verses and technique, Learning through Music.

5. Show and suggest pedagogical approaches whereby teachers are able to see the classroom application of the Quranic Verses in English

6. Reexamine objectives achieved

7. Highlight this paper's contribution to the thematic expression of teaching and learning process of university education as a service to multiculturalism, diversity and globalism. 


\section{CURRENT RESEARCH ON USING MUSIC IN THE LANGUAGE CLASSROOM}

Research on using music in the language classroom has been delved into quite some time ago. Its benefits have been found to be helpful in the learning process. For example, Medina (1993) says that music is felt to be advantageous to language learning. Music use in the second language classroom is consistent with both of Krashen's (1989) hypotheses: The Input Hypothesis and The Affective Filter Hypothesis.

More recently speaking, Panse (2009) gives some advice and points out how music can help in improving the listening comprehension skills of ESL learners:

When using music in the classroom to improve listening comprehension skills, it is generally advisable to -

1. Choose songs with clear and understandable lyrics, at least at the start, as beginners might have trouble understanding colloquial lyrics.

2. Equip the class with print copies of the lyrics.

3. Select songs that the students like, are familiar with, or can relate to.

4. Use songs that can help with cultural understanding of the language.

5. Use songs that will remain interesting even after repeated listening.

6. Use cheerful, humorous songs. Never anything violent or offensive.

Using music, you can improve listening comprehension skills by -

1. Intensive learning - This is mostly the work done in the classroom, involving repetitive listening and singing along with the song, noting the words in the lyrics, memorizing them and discussing the word meaning as well as the song meaning.

2. Extensive learning - This is where you listen to a wide variety of music without any pressure to understand exactly what you're hearing. Extensive learning is somewhat like osmosis, you let the understanding seep in gradually.

Both intensive and extensive learning are essential. It'll also help if you equip yourself with knowledge of the regional, social and cultural background of the language you are learning. An understanding of these will support the listening ability.

Professor Larry M. Lynch (2012) lists 9 reasons why a teacher should use songs to teach EFL:

(Panse, 2009)

Language teachers can and should use songs as part of their classroom teaching repertoire. Songs contain authentic language, are easily obtainable, provide vocabulary, grammar and cultural aspects and are fun for the students. They can provide valuable speaking, listening and language practice in and out of the classroom. Some key reasons songs can work exceedingly well in the foreign language classroom include the following:

1. Songs almost always contain authentic, natural language.

2. A variety of new vocabulary can be introduced to students through songs.

3. Songs are usually very easily obtainable.

4. Songs can be selected to suit the needs and interests of the students.

5. Grammar and cultural aspects can be introduced through songs.

6. Time length is easily controlled.

7. Students can experience a wide range of accents.

8. Song lyrics can be used in relating to the situations of the world around us.

9. Students think songs are natural and fun.

Arevalo (2010) states the link between songs and culture:

(Lynch, 2012)

First of all, there is that aspect of communicative competence which enables a foreign-speaker of a language to understand the ways in which a language can be used in specific sociocultural contexts and can refer to the cultural knowledge and pre-suppositions of specific groups of native-speakers. Second, there is the ability of a foreign-speaker to reflect upon his/her own culture, how it appears to outsiders, and how a relationship can be established between it and the cultures of others in order to facilitate communication, despite different cultural perspectives. Third, there is the ability of the teacher of foreign languages to mediate between learners' cultures and others, to help learners to acquire their own capacity for mediation, and to stimulate learners' interest in other cultures in general, irrespective of the link with a specific language.

A song-based approach relies on authentic texts as the underlying linguistic linchpin to connect language acquisition to cultural literacy and thereby addresses concerns raised recently about how to develop a practical classroom pedagogy that leads students to more knowledge about the target language while pursuing a cultural studies agenda. Teachers, therefore, might want to elaborate on songs with a particular sociopolitical context or literary history that lie within a specific musical genre closely associated with their language of instruction.

(Arevalo, 2010) 


\section{MAIN OBJECTIVES OF A CRITICAL READING SESSION}

Saunders et al (1999) revealed four strategies which work and these four strategies are tied with the literary text or reading material used in class. These four points can also be used as a basis or objectives or intended learning outcomes that a teacher would want to achieve at the end of a critical reading session, including the four language skills. Thus, at the end of a critical reading session, a teacher would want students to have exercised and practiced in these areas:

1. Build students' background knowledge.

2. Draw on students' personal experiences.

3. Promote extended discourse through writing and discussion.

4. Assist students in rereading the pivotal portions of the text.

5. Use of four language skills

(Saunders et al, 1999:4)
- Reading
- Writing
- Listening
- Speaking

This writer has modified Vogt and Echevarria's musical technique. This writer's "Learning Through Music" has used music and its lyrics as a contributive factor to the actual learning process in terms of content ties with the literary text used in the classroom.

Vogt and Echevarria came up with a technique used to enhance language skills through critical reading. The technique is called "Milling to Music". The highlights of this technique are:

The teacher uses music as a background soothe as students carry out prompts from the teacher.

For example:

- After hearing the prompt, the students take turns sharing their responses with their partner.

- When the music starts again, all students walk around the classroom.

- When the music stops, each student finds a new partner and quietly waits for the next prompt from the teacher.

This process continues until all of the question prompts are answered.

(Vogt and Echevarria, 2008)

\section{Using Information Technology}

It is possible for teachers to download the Quranic verses in English from websites. The difference between the material on the website and in the book is the arrangement. The material in the book is arranged with a certain style where distinct spacing of verses shows different sections of a surah. The material on the website is plain and runs through in the same way to the end. For this particular study, there are some helpful websites where teachers can download Islamic songs on a CD for classroom use.

For websites with songs with Quranic topics or titles:

It comes with lyrics of each song, a list of artists or sings and songs. Retrieved from http://www.islamiclyrics.net/ on June $30^{\text {th }}, 2012$.

Retrieved from http://www.nasyid-online.com/ on June $30^{\text {th }}, 2012$.

This is the website of a Muslim hip-hop group. Halal nasheeds.

Retrieved from http://www.nativedeen.com/myvoice/ on June $30^{\text {th }}, 2012$.

Retrieved from http://www.youtube.com/watch?v=1A 7vSkVDm8M\&feature=related on June 30 ${ }^{\text {th }}, 2012$.

This website has features various Malaysian groups including Raihan, Rabbani and more. Artists use Malaysian percussion instruments.

One of the most popular Islamic songs by Raihan is entitled "Thank you Allah".

Retrieved from http://www.youtube.com/watch?v=iT6ByMPR5Eo on June $30^{\text {th }}, 2012$.

More useful websites in assisting teachers for classroom use of Quranic verses in English can be found in APPENDIX 2.

\section{Quranic Literature Log Of A Researcher}

This particular paper marks the fourteenth paper of a well-thought out plan of this writer for a life-long pursuit of a Quranic Literature Log of her own but perhaps not in the same meaning to that used for a student's Literature Log. This writer will start having a folder of her own called Quranic Literature Log where a list of 
selected Quranic verses in English by various translators to be used as literary texts or reading material are merged with the technique through various sources for teaching in the Language and Literature classroom. Through this log, a series of new research papers will be written and published.

For this study specifically, the entry which relevantly and tentatively informs is as shown in Table 1- Quranic Literature Log:

Table 1- Quranic Literature Log

Quranic Verses: (APPENDIX 1)

Verse 49 of Surah Al-Ankaboot(29) (The Spider)

Verse 190 of Surah Ali- Imran(3) (The Amramites)

Verse 88 of Surah Al-Naml (27) (The Ant)

Verse 33 of Surah Al-Anbya(21)(The Prophets)

Verse 40 of Surah Yasin(36)(Y.S.)

Verse 5 of Surah Al-Zumar(39)(The Throngs)

Verses 27-33 of Surah AlNaazeaat(79)(The Snatchers)

Topic of verses: Proof of the Existence and Greatness of Allah

Source of Text: www.Quranix.com

The Qur'an: A Reformist Translation by Dr.EdipYuksel, LaythSaleh al-Shaiban and Dr.Martha Schulte-Nafeh

(Yuksel,al-Shaiban and Nafeh, 2007)

http://www.quranix.com/\#?RTQ=1\&A=1\&L=en\&NA=10\&S=94\&SA=1

Technique: Learning Through Music (Milling to Music)

Source of Technique: Vogt, M.E. and Echevarria, J. (2008).99 Ideas and Activities for Teaching English

Language Learners with the SIOP Model . Boston, Mass: Pearson Education.

Song: Open your Eyes

Sung by: Maher Zain, Lyrics(APPENDIX 4)

Source: http://www. youtube.com/watch?v=1OVCtNjnN2A

THE LESSON PLAN

Technique: Learning Through Music (Milling to Music)

Text: Verses: Selected Verses from Various Surah (APPENDIX 1) as shown in Table 2- Selected Verses:

Table 2- Selected Verses

Verse 49 of Surah Al-Ankaboot(29) (The Spider)

Verse 190 of Surah Ali- Imran(3) (The Amramites)

Verse 88 of Surah Al-Naml (27) (The Ant)

Verse 33 of Surah Al-Anbya(21)(The Prophets)

Verse 40 of Surah Yasin(36)(Y.S.)

Verse 5 of Surah Al-Zumar(39)(The Throngs)

Verses 27-33 of Surah AlNaazeaat(79)(The Snatchers)

Level: Intermediate (undergraduate)

Duration: Two Hours

The following are the main objectives of a Critical Reading session:

\section{Objectives:}

1) Build students' background knowledge: Done in bringing focus to the benefit of reflections and discipline because there exists Allah. Students' awareness is raised about the miracles around us.

2) Draw on students' personal experience: Done in Homework writing assignment where students are asked to relate about their own experience.

3) Promote extended discourse through writing and discussion: Done in discussing and clarifying they have understood and written down the explanations from peers or the teacher when linking one verse of song to Quranic verses.

4) Assist students in rereading the pivotal portions the text: Done in discussions of Quranic verses, one verse at a time and then linking one verse of song to Quranic verses.

5) Use the four skills:

i) Listening: Done in listening to teacher's explanations of verses and member's explanation in linking cong verse to Quranic verses. 
ii) Speaking: Done in explaining to each other on linking song verse to Quranic verses. Done in presentation of explanation of group's reasons for the linkages.

iii) Reading: Done in reading Quranic verses individually in attempting to make linkages. Done in reading song verses while singing.

iv) Writing: Done in writing what they have understood from peers and teacher on the verses. Homework Writing Assignment is on personal experience.

The teacher can begin by distributing copies of the English translated version of the Quran by Dr Edip Yuksel, selected verses from various Surah (APPENDIX 1), and informing the students where the text is from and also the person who translated the text. The teacher is also ready with another handout of lyrics (APPENDIX 4) for distribution and a CD of the song downloaded from the website: Retrieved from http://www.weblagu.com/13Open-Your-Eyes---Maher-Zain-id-UmhWRIBCQTA.html on June $30^{\text {th }}, 2012$.

The teacher can begin the lesson by saying that today's lesson is about raising our awareness to the things that are around us in order to be grateful for what we each have. Then the teacher can inform students on the activities that the students will be participating in for the session.

The teacher can begin by asking the students to read the verses on the handout from selected various surah, all depicting miracles from God which some of us want to enjoy and not be grateful for. Instead we want to forget the existence of The Most Powerful Being and Creator-God, not realizing that it is to our advantage that we can go about our lives with certainty that there is God up above watching over us. However, there must be conviction of Belief within each one of us which comes with a sense of gratitude and complete submission.

Then the teacher can go through each verse to raise student's awareness of the miracles that we take for granted, for example, the successive changes of day and night. For each verse, the teacher has prepared to highlight several vocabulary words. For example as shown in Table 3- Vocabulary:

Table 3- Vocabulary

\begin{tabular}{l} 
Verse 49 of Surah Al-Ankaboot(29) (The Spider) \\
$29: 49$ In fact, it is a clear revelation in the chests of those who have been given knowledge. It is only the wicked who doubt Our \\
signs. \\
\hline Vocabulary words: \\
Revelation: \\
Wicked: \\
Doubt:
\end{tabular}

As the teacher goes through each verse, the teacher makes sure that these vocabulary words are being explained in context. The teacher reminds students to take notes of the meanings for use later on in the session. The teacher goes through and explains every verse on the handout.

Then the teacher breaks students up into four groups. The teacher explains that they will hear a song sung by Maher Zain. The teacher mentions that the song has ten verses. The teacher distributes the lyrics of the song (APPENDIX 4). Verses 2,5,8 are repetitions and so are verses 3,6,9. They are called verses of chorus in songs. In the context of this song, it is urging its listeners to be aware of our surroundings which are God's creations. Special attention is asked by teacher for verses $1,4,7,10$. The students are then asked to look at each of the verses in the song (verses 1,4,7,10), then to connect which Quranic verses are being talked about in the song. Each group will concentrate on linking one verse of the song to the Quranic verses. For example, the group which will concentrate on linkages with verse one:

1. Look around yourselves

Can't you see this wonder

Spread in front of you

The clouds floating by

The skies are clear and blue

Planets in the orbits

The moon and the sun

Such perfect harmony

Verse 1 of the song is talking about or making mention of these Quranic verses:

27:88 You see the mountains, you think they are solid, while they are passing by like the clouds. The making of God who perfected everything. He is Ever-aware of what you do.

Verse 33 of Surah Al-Anbya(21)(The Prophets) 
21:33 He is the One who created the night and the day, and the sun and the moon, each swimming in an orbit. Verse 40 of Surah Yasin(36)(Y.S.)

36:40 The sun is not required to overtake the moon, nor will the night precede the day; each of them is swimming in its own orbit.

Verse 5 of Surah Al-Zumar(39)(The Throngs)

39:5 He created the heavens and the earth with truth. He rolls the night over the day, and He rolls the day over the night. He committed the sun and the moon, each running for an appointed term. Absolutely, He is the Noble, the Forgiving.

Verses 27-33 of Surah AlNaazeaat(79)(The Snatchers)

79:27 Are you a more powerful creation than the sky which He built?

Thus, the groups will provide links of the lyrics to the Quranic verses. A spokesperson for each group will present the group's linkages and reasons. Then the teacher will give a Homework Writing Assignment: Reflect and relate one miracle that you have seen or know about in your life. Can you explain how and why it happened?

The rest of the session can now be spent on singing and enjoying the beautiful song.

The teacher says the song will be played once through and then the class can sing this beautiful song when it is played the second time around. The students sing the song several times. The teacher will play the song again with one group singing the verse they were assigned to link and then altogether for the verses of chorus.

\section{Conclusion}

Teachers are aware that having a classroom with mixed or differing abilities is a challenging task on the teacher's shoulders. A good teacher rarely follows a textbook step by step as many aspects of teaching and learning need to be taken into consideration. With mixed abilities or all with the same level of ability, a teacher must create opportunities for students to demonstrate each one's level of knowledge and to create opportunities for students to express the way each one thinks. Differentiation practice in classroom strategy and in assessment strategy is always a useful tool for teachers to equip themselves with for more effective teaching and learning.

Where assessment is concerned, evaluation is then called for but still heeding the differentiation approach. The assessments should reflect both social and academic performance. Therefore evaluation of assessment should involve all of the following:

1. Completion of task

2. Ability to understand through listening to teacher and peers

3. Ability to explain or make connections or predict in material and content

4. Ability to demonstrate individuality and creativity

5. Availability and ability to make choices in tasks which consider flexibility for different strengths and needs.

This technique, Learning Through Music (Milling to Music), text of selected Quranic verses in English and the suitable activities carried out in the classroom, each plays its own role in a teacher's successful critical reading session. They are an integral part of the whole teaching session. The same set of intended learning outcomes or objectives was achieved at the end of the Quranic Critical Reading session.

\section{References}

[1]. Arevalo, E.A. (2010). The Use of Songs as a Tool to Work on Listening and Culture in EFL Classes. Cuadernos de Linguistics Hispanica N. Retrieved from dialnet.unirioja.es/servlet/fichero_articulo?codigo=3673475on July $28^{\text {th }}, 2012$.

[2]. Krashen, S. (1982). Principles and Practice in Second Language Acquisition. Oxford: Pergamon Press. Retrieved from http://www.scribd.com/doc/48535797/Using-Music-to-Enhance-Second-Language-Acquisition-From-Theory-to-Practice on June $30^{\mathrm{th}}, 2012$.

[3]. Krashen, S. (1989). We acquire vocabulary and spelling by reading: Additional evidence for the input hypothesis. Modern Language Journal, 73 (4), 440-464. Retrieved from http://www.scribd.com/doc/48535797/Using-Music-to-Enhance-SecondLanguage-Acquisition-From-Theory-to-Practice on June $30^{\text {th }}, 2012$.

[4]. Lynch, L. (2012). 9 Reasons Why You Should Use Songs to Teach EFL. ESL Base Teach English. Retrieved from http://www.eslbase.com/articles/songs on July $28^{\text {th }}, 2012$.

[5]. Medina, S. (1993). The effect of music on second language vocabulary acquisition. FEES News (National Network for Early

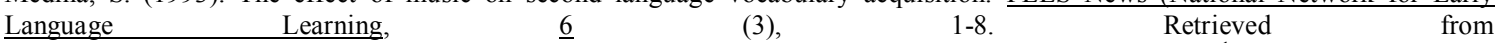
http://www.mextesol.org.mx/contenidos/Summer\%20Vol.\%2026\%20No.\%201\%20\%202003.pdf on June 30 $3^{\text {th }}, 2012$.

[6]. Panse, S. (2009). Edited by Rebecca Scudder. Using Music to Improve Listening Comprehension Skills. Bright Hub Inc. Retrieved from http://www. brighthub.com/education/languages/articles/21693.aspx on July $28^{\text {th }}, 2012$.

[7]. Saunders, W., O'Brien, G., Lennon, D., \& McLean, J. (1999). Making the transition to

[8]. English literacy successful: Effective strategies for studying literature with transition

[9]. students. Educational Practice Reports, Center for Research on Education, Diversity and Excellence, UC Berkeley. Retrieved from http://escholarship.org/uc/item/1574p5t1\#page-4 on June $30^{\text {th }}, 2012$.

[10]. Vogt, M.E. and Echevarria, J. (2008).99 Ideas and Activities for Teaching English Language Learners with the SIOP Model . Boston, Mass: Pearson Education. 


\section{APPENDIX 1 \\ THE DISCUSSION OF THE SEVERAL SELECTED VERSES BY DR EDIP YUKSEL \\ In the name of God, the Gracious, the Compassionate}

The teacher can explain that the reverence and respect to the Almighty precedes every surah or chapter of the Quran. These words emphasize that the verses that follow are indeed from the Almighty. These words underscore the authenticity of the Quran. The words Gracious and Compassionate are some of attributes of Allah and these words are also two of His ninety-nine names.

Verse 49 of Surah Al-Ankaboot(29) (The Spider)

29:49 In fact, it is a clear revelation in the chests of those who have been given knowledge. It is only the wicked who doubt Our signs.

If we are honest within ourselves, we could surely see all God's creations.

Verse 190 of Surah Ali- Imran(3) (The Amramites)

3:190 In the creation of heavens and earth, and the difference between night and day, are signs for those with intelligence.

He is the Creator of the heavens and the earth, and the successive changes of night and day. Our intelligence would know that these are some of the proof of God's existence.

Verse 88 of Surah Al-Naml (27) (The Ant)

27:88 You see the mountains, you think they are solid, while they are passing by like the clouds. The making of God who perfected everything. He is Ever-aware of what you do.

We see the mountains so high as if the clouds are passing by them. These are some of perfect creations of God.

God is All-Aware of everything we do.

Verse 33 of Surah Al-Anbya(21)(The Prophets)

$21: 33 \mathrm{He}$ is the One who created the night and the day, and the sun and the moon, each swimming in an orbit. God is the Creator of the successive changes of night and day, and sun and moon which are up above in an orbit.

Verse 40 of Surah Yasin(36)(Y.S.)

36:40 The sun is not required to overtake the moon, nor will the night precede the day; each of them is swimming in its own orbit.

Each successive change comes in the exact perfect moment, each of them in its own orbit.

Verse 5 of Surah Al-Zumar(39)(The Throngs)

39:5 He created the heavens and the earth with truth. He rolls the night over the day, and He rolls the day over

the night. He committed the sun and the moon, each running for an appointed term. Absolutely, He is the Noble, the Forgiving.

He is the True Creator of the heavens and the earth. Night and Day comes at the exact perfect moment with everlasting movement of successive change between them. God is Absolute, All-Noble, The Most Forgiving.

Verses 27-33 of Surah AlNaazeaat(79)(The Snatchers)

79:27 Are you a more powerful creation than the sky which He built?

Are any of us more powerful than The Creator of the sky?

79:28 He raised its height, and perfected it.

God created the sky so high above us and shaped it perfectly.

79:29 He covered its night and brought out its morning.

God created the successive changes of night and day.

79:30 The land after that, He made it like an egg.

God created the land on earth and flattened earth so perfectly at both ends to form the North and South poles.

79:31 He brought forth from it its water and pasture.

God created water coming out from the land and pasture on earth.

79:32 The mountains He fixed firmly.

God created the high mountains standing tall and upright.

79:33 All this to be a provision for you and your livestock.

God created all of these as a provision for humans and for the animals that we raise to later consume ourselves. 


\section{APPENDIX 2}

\section{USING INFORMATION TECHNOLOGY}

USEFUL WEBSITES:

1. English Index Categorization Alphabetical List of Topics in the Quran: Retrieved from http://www.quranictopics.com/p3ch1-e.html on June 30th, 2012.

2. The English Translation of The Holy Quran Online: Retrieved from http://jannah.org/quran/ on June $30^{\text {th }}, 2012$.

3. Islamicity.com-The Holy Quran. The translations are available in multiple languages. Retrieved from http://www.islamicity.com/mosque/quran/ on June $30^{\text {th }}, 2012$.

4. The way each verse is dealt with by each translator or group of translators is so thorough. After the translation of each verse, a thorough endnote presentation capturing the essence of the surah is laid out. This website is especially useful for researchers and students in the field of translations and comparative literary studies. Retrieved from http://www.quranix.net/\#?RTQ $=1 \& T M G=1 \& M A=1 \& R K=1 \& \mathrm{SH}=1 \& \mathrm{TE}=1 \& \mathrm{~A}=1 \& \mathrm{~L}=\mathrm{en} \& \mathrm{NA}=10 \& \mathrm{~S}=1$ on June $30^{\text {th }}, 2012$.

5. A linguistic resource showing the theoretical aspects of linguistics: Arabic grammar, semantics, pragmatics, lexicology, phonology, morphology and syntax of each word in the Quran, the descriptive aspects of linguistics: comparative linguistics, etymology, phonetics and sociolinguistics of words and phrases in the Quran, and the applied linguistics aspects: language and vocabulary development, psycholinguistics and stylistics of the words and phrases in the Quran. At the end of each surah, there is an audio Quran recitation of the surah by the recitor, Saad AlGhamadi. Retrieved from http://corpus.quran.com/wordbyword.jsp on June $30^{\text {th }}, 2012$.

\section{APPENDIX 3 \\ CLASSROOM APPLICATION OF QURANIC VERSES IN ENGLISH \\ Quranic Verses in English: Teaching Imagery}

In the case of Descriptive imagery, an illustrated example is from Abdullah Yusuf Ali's English Translations of the Quran, Verse 29 of Surah(18) Al-Kahf:

\section{Surah (18) Al-Kahf}

Verse 29, line 9: That will scald their faces

What type of imagery? Descriptive imagery.

The image gives a vivid description of what the "water like melted brass" can do.

Senses: visual, tactile.

Not only can one imagine feeling the pain of being scalded but one can also picture the disfigurement that the scalding will cause to the faces of the sinners.

In the case of Figurative imagery using the literary device, simile, an illustrated example is from Abdullah Yusuf Ali's English Translations of the Quran, Verse 65 of Surah(37) As-Saffat:

Surah(37) As-Saffat

Verse 65, lines 1-3: $\quad$ The shoots of its fruit-stalks

Are like the heads

Of devils

What type of imagery? Figurative Imagery using the literary device: simile.

The word "like" tells one that a simile is being used to compare the shoots to devils' heads.

Senses: visual.

This image gives a vivid picture in our minds of how evil-looking fruits of this tree in Hell are.

In the case of Figurative imagery, using the literary device, metaphor, an illustrated example is from Abdullah Yusuf Ali's English Translations of the Quran, Verse 50 of Surah(38) Sad:

Surah (38)Sad

Verse 50, lines 2 and 3: Whose doors will (ever)

Be open for them

What type of imagery? Figurative imagery using a literary device: metaphor. 
These doors to the beautiful gardens are forever open to the righteous. Normally, when one thinks of doors, they can either be open or closed. But these doors in Heaven will forever be open. The image metaphorically compares the entrance or passage into Heaven, which we cannot truly visualize, to "doors" in which case Heaven is compared to a gracious house or one's eternal home. The image of open doors depicts Heaven as an abode that feels familiar, hospitable, welcoming.

Senses : visual.

The image suggests a mental picture.

In the case of Figurative imagery using the literary device, symbol, an illustrated example is from Abdullah Yusuf Ali's English Translations of the Quran, Verse of Surah(15) Muhammad:

\section{Surah (47) Muhammad}

Verse 15, lines 6-8: $\quad$ Rivers of milk

Of which the taste

Never changes

What type of imagery? Figurative imagery using a literary device: symbol.

Again, unlike the earthly milk which can turn sour without refrigeration, this "milk" in Heaven tastes forever fresh. This "milk" can be found in the form of rivers-- in abundance.

Sense: visual, gustatory, tactile, olfactory.

This image makes one imagine whether this "milk" looks like that consumed on earth; how delicious it must taste, and cool it must feel, and fresh it must smell.

\section{QURANIC VERSES IN ENGLISH: STYLISTICS APPLICATION}

An illustrated example of a stylistics analysis of Quranic verses in English by translated by Muhammad Asad is Verses 16-18 of Surah(77) Al-Mursalat:

(16) Did We not destroy [so many of] those [sinners] of olden days? (17)And We shall let them be followed by those of later times : (18) [for] thus do We deal with such as are lost in sin.

Analysis: Verses sixteen to eighteen are put together to form one paragraph. These verses explain the punishment that awaits sinners in the Day of Judgement-destruction. Verse sixteen questions and verses seventeen and eighteen answers verse sixteen. Verse seventeen begins with the conjunction "And" and is in the future tense and verse eighteen begins with the conjunction [for] followed by "thus" and is in the present tense. Verse seventeen implies that suffering in the hereafter is bound to befall the sinners of later times even if God wills to spare them in this world. "We" is used to refer to God in these verses. These verses show the timelessness, universality and unchanging laws of God - for the past, present and future - sinners are destroyed.

An illustrated example of a stylistics analysis of Quranic verses in English by Abdullah Yusuf Ali is Verse 27 of Surah (77) Al-Mursalat:

27. And made therein

Mountains standing firm

Lofty (in stature);

And provided for you

Water sweet (and wholesome)?

Analysis: Verse twenty-seven tells one of Allah's creative activity and hence, His existence when it is evident that mountains-hard and solid, high in altitude - are able to distribute or provide man with pure delicious, sweet water in the form of rivers and springs. The conjunction "and" is used twice in lines one and four. The metaphor is describing the mountains as "standing firm, lofty (in stature)" suggests that these mountains are hard, solid and tall or high in altitude. The word, "wholesome", suggests pure and untouched by man. If the wisdom and power of Allah can do so much before our eyes, we therefore, cannot reject His teaching of a still more wonderful future life after death. Verses twenty-five to twenty-seven are in the past tense.

APPENDIX 4

Open Your Eyes (Lyrics)

By Maher Zain

1. Look around yourselves

Can't you see this wonder

Spread in front of you 
The clouds floating by

The skies are clear and blue

Planets in the orbits

The moon and the sun

Such perfect harmony

\section{CHORUS}

2.Let's start question in ourselves

Isn't this proof enough for us

Or are we so blind

To push it all aside..

No.. We just have to

3. Open our eyes, our hearts, and

minds

If we just look bright to see the signs

We can't keep hiding from the truth

Let it take us by surprise

Take us in the best way

(Allah..)

Guide us every single day..

(Allah..)

Keep us close to You

Until the end of time.

4.Look inside yourselves

Such a perfect order

Hiding in yourselves

Running in your veins

What about anger love and pain

And all the things you're feeling

Can you touch them with your hand?

So are they really there?

\section{CHORUS}

5.Lets start question in ourselves

Isn't this proof enough for us?

Or are we so blind

To push it all aside..?

No..

6. We just have to

Open our eyes, our hearts, and minds

If we just look bright to see the signs

We can't keep hiding from the truth

Let it take us by surprise

Take us in the best way

(Allah..)

Guide us every single day..

(Allah..)

Keep us close to You

Until the end of time..

7.When a baby's born

So helpless and weak

And you're watching him growing..

So why deny

Whats in front of your eyes

The biggest miracle of life.

CHORUS

8. We just have to

Open our eyes, our hearts, and minds

If we just look quiet we'll see the signs

We can't keep hiding from the truth 
Let it take us by surprise

Take us in the best way

(Allah..)

Guide us every single day..

(Allah..)

Keep us close to You

Until the end of time..

9.Open your eyes and hearts and minds

If you just look bright to see the signs

We can't keep hiding from the truth

Let it take us by surprise

Take us in the best way

(Allah..)

Guide us every single day..

(Allah..)

Keep us close to You

Until the end of time..

10.Allah..

You created everything

We belong to You

Ya Robb we raise our hands

Forever we thank You.

Alhamdulillah.

Retrieved from http://www.weblagu.com/13-Open-Your-Eyes---Maher-Zain-id-UmhWRIBCQTA.html on June $30^{\text {th }}, 2012$.

Retrieved from

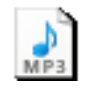

13. Open Your Eyes - Maher Zain.mp3

on June 30th, 2012. 